\title{
DESIGN CONTRIBUTIONS TO BUILDING TECHNOLOGY: GOALS, INTERFACES AND RESPONSIVENESS
}

\author{
Boess, Stella U. \\ Delft University of Technology
}

\begin{abstract}
In this paper, I identify issues that arose in a recent pilot project in which designers contributed to the construction field. The project was led by an overall responsible innovation goal for sustainability impact: contribute to global $\mathrm{CO} 2$ reduction. The innovation solution being developed to achieve this goal was a sustainable renovation concept intended for upscaling. In this pilot project, it was applied to a social housing block of 12 apartments. The designers sought to help align technical solutions with the residents' later use of their homes, because the latter is an important factor in achieving a zero-energy outcome. The paper identifies four issues that arose in the collaboration between design and construction and installation professionals. The issues are goal translation, goal dissipation, the contested service interface and the contested responsiveness to residents. I argue that designers can engage and contribute through design intervention and applying care in the collaboration, in order to support the success of responsible innovation.
\end{abstract}

Keywords: Design practice, Design for interfaces, Case study, Building industry, Impact goal

Contact:

Boess, Stella U.

Delft University of Technology

Industrial Design Engineering

The Netherlands

s.u.boess@tudelft.nl

Cite this article: Boess, S.U. (2019) 'Design Contributions to Building Technology: Goals, Interfaces and Responsiveness', in Proceedings of the 22nd International Conference on Engineering Design (ICED19), Delft, The Netherlands, 5-8 August 2019. DOI:10.1017/dsi.2019.328 


\section{INTRODUCTION}

This paper presents a reflection from a design perspective on a building industry development and implementation process case that recently took place, with a focus on the issues around home interfaces. The reflection is based on a case that was recently completed. This case was led by a sustainability impact goal: to contribute to global $\mathrm{CO} 2$ reduction by realising an innovative zeroenergy pilot renovation of a block of 12 apartments, with a view to upscaling the approach. The case presents a valuable opportunity for reflection because the development process was not driven by a specific guiding design methodology, but primarily by the pragmatic goals of a construction company and its network partners. The value in this case for a reflection lies in two aspects:

- $\quad$ its complexity, because it had to fulfil a range of business, technical and implementation goals for a client, while delivering an innovation, and

- $\quad$ its overarching goal, which was to contribute to global $\mathrm{CO} 2$ reduction. With that, it is a case of responsible innovation in aim, following this definition: "responsible innovation means taking care of the future through collective stewardship of science and innovation in the present." (Stilgoe, Owen and Macnaghten 2013). According to these authors, it means considering as much as feasible the impacts of the innovation in terms of benefits and risks, in collaboration. The case presented challenges and learnings for responsible innovation. I share these learnings here because they can help equip designers with recognition when they face similar challenges, hopefully leading to strategies how to address them in responsible innovation. In the words of Stilgoe, Owen and Macnaghten 2013, "such that an improved - more democratic or more legitimate - consideration of ends becomes possible".

The construction company was in the lead throughout the project, and an academic partner consortium contributed input and advice as well as monitoring on indoor quality, technical realisation and business models. The impact goal was to make sustainable renovation feasible for the European housing association market and thus contribute to global $\mathrm{CO} 2$ emissions reduction. The consortium received funding to support the construction company's efforts with research and to help with a pilot realisation even though it is not yet fully feasible financially. Responsible innovation according to the definition given above involves the dimensions of anticipation, reflexivity, inclusion and responsiveness (Stilgoe, Owen and Macnaghten 2013). In this paper I focus on the stakeholders' efforts to apply them in a particular part of the project: that of the interactions that the residents would have with the new set-up of their homes. This focus of the paper is chosen for these reasons:

- it has previously been shown that the residents' use of their home systems affects the success of actual low-energy consumption outcomes. This has often been discussed as a 'rebound effect' (residents use more energy because they assume their devices are now low-energy-using), but actually much is not known about this yet, and could also have other causes such as inaccurate assumptions about prior energy use (Guerra-Santin et al., 2018.) or residents' inability to understand their home systems (Chiu et al., 2014). There is a need for further insight.

- the residents' future use of their house is part of my particular research concern from an interaction perspective (e.g. Pasman, Desmet and Boess 2011; Boess and Kanis 2008).

I acknowledge that designers' role in processes such as these are limited (Coutts et al., 2017). Yet also with Coutts et al., 2017 I argue that designers have a contribution to make to the impact goal of a responsible innovation through both design intervention and applying care in the collaboration.

\subsection{The case}

A construction SME is in the lead in a networked collaboration with academics and other SMEs. Networked collaboration (characterised as heterogenous entities collaborating on equal terms) is typical of SMEs. They contribute significantly to EU economies in terms of gross value added and employment (EU undated), and hence in their effect on citizens (De Lille and Buur 2010). This paper is written from the perspective of a design academic collaborating primarily with the construction SME, and secondarily, with their other collaborators as well as the residents. The construction SME featured in this paper, an innovator in its field, is the first in its country to deliver a scalable zeroenergy renovation of outdated multi-story housing (Figure 1), an environmentally better approach than rebuild. This now completed pilot renovation is of a 12-household block of flats dating from 1951. 
The process took one year from the client approving the project, to planning the project and informing the residents, obtaining the residents' approval, planning the renovation in detail, carrying it out over a six-week period, and delivering the result. With others, I have described the general process of facilitating resident participation earlier (Boess, Silvester, de Wal and de Wal 2018) and evaluated the project as successful upon delivery: the building conformed to national zero-energy regulations and the residents were satisfied with their improved, comfortable homes. All stakeholders had anticipated that the residents would have a crucial in the success of the project. For example, to achieve energy goals, it is key that the residents keep their windows closed while their heating system is on. Balanced ventilation with heat recovery provides fresh air. However, a known risk is that some residents may prefer to open windows to aerate their homes daily, which results in energy spillage in winter. Consequently, me and other design researcher stakeholders in this project set out to support residents' individual preferences and to enable them to integrate new technologies into their everyday practices. Our approach was to enable to align the renovation with personal needs such as safety and comfort, even if they did not share global climate goals, as explained by Chiu et al., 2014. The renovation is carried out with a novel combination of relatively new technologies, which means that new connections have to be made between interface elements the residents will eventually use. Our research questions in this were, in relation to the focus of this paper:

- What are the contributions of a design approach in a building process with its stakeholders?

- How do the activities and deliverables promote or impede responsible innovation?

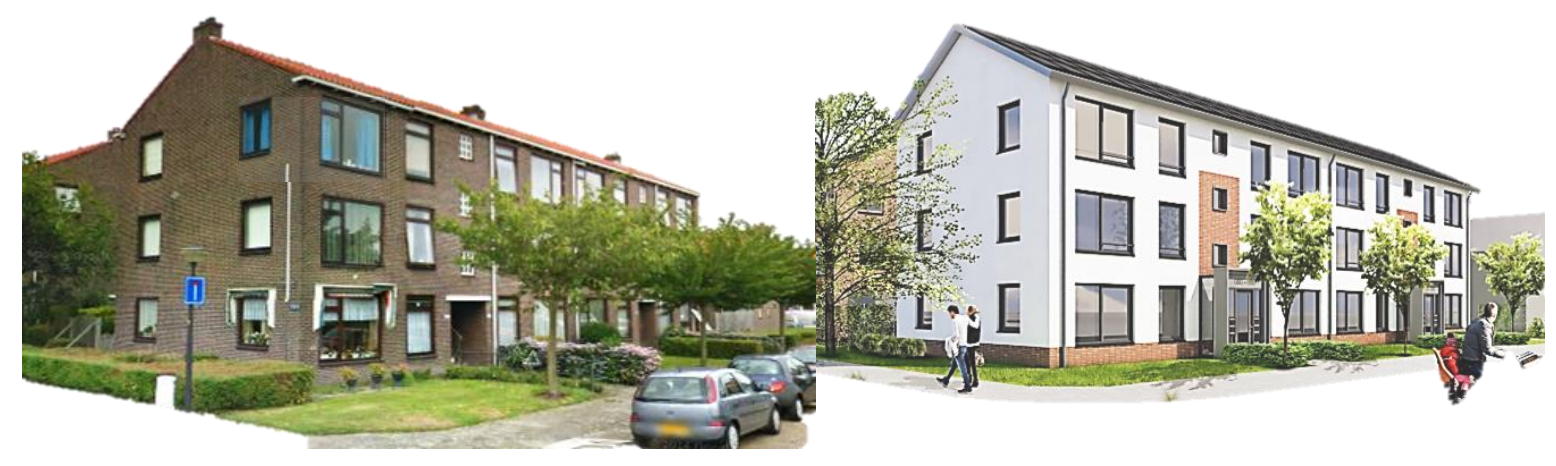

Figure 1. Before- and after depiction of the completed zero-energy pilot renovation of a block of 12 flats from 1951.

\section{METHOD}

In this paper I reflect on insights gathered throughout the implementation process from the moment the residents opted in to the renovation project, and until the renovation had taken place and adaptions were made based on initial insights into the residents' use of their home and systems. I present reflexive ethnographic narratives from this process (Blomberg and Karasti 2012, Bervall-Kåreborn and Ståhlbrost 2008), sorted into themes, as I have done previously (Boess, Silvester, de Wal and de Wal 2018). This approach entails leveraging ethnographic documentation and analysis approaches in everyday settings, taking a holistic view on the process, providing descriptive understandings and showing members' point of view (Blomberg and Karasti 2012, p. 88). I also adhered to the commitments of participatory design and, in the language of responsible innovation, to inclusion and responsiveness, by respecting different knowledge, creating opportunities for mutual learning, jointly negotiating project goals, and applying tools and processes to facilitate design (Blomberg and Karasti 2012 , p. 88). However, unlike in a previous reflection, this paper is written specifically from the designer perspective, in order to develop learnings for designers in supporting responsible innovation in stakeholder processes. I took part in regularly meetings with the main contact stakeholder, the construction company, to discuss progress and plan future steps. Besides these close collaboration meetings, there were occasional work meetings with the other stakeholders such as the installation supplier, which served alignment and were separate from the direct contract negotiations between construction company and supplier. Figure 2 shows the network of stakeholders involved in the 
implementation process, revealing its complexity and how it limits how much stakeholders can each oversee the full benefits and risks to the overall goal.



Figure 2. Stakeholders involved. Figure based on van den Elzen (2018). The construction company is in the lead in a networked collaboration.

I and the other stakeholders also regularly met informally with the residents in their residential setting and kept records of this. I frequently video recorded these encounters with all stakeholders' permission, making sure not to record or share any identifying information. Of the initially 12 households, one home was vacated before the renovation period, and one resident elected to not participate in any communication beyond that which directly concerned the renovation of their home. 10 households participated regularly in encounters with me and thus were the source of learnings for this paper on the resident side. Six of these households were single residents, two couples and two had occasional second residents. The collaborating residents were seven men and four women ranging in age from 30 to 80 . All were native language speakers except one foreign-language couple who partly used translator services, including for all written material.

The next section presents themes I identified from the stakeholders' efforts to realise responsible innovation in a particular aspect of the project: that of the interactions that the residents would have with the new set-up of their homes.

\section{RESULTS}

\subsection{Theme: goal translation}

This theme traces how the stakeholders translate the overall impact goal of global CO2 emissions reduction into different goals throughout the process, and how this ultimately affects the residents' contribution to the overall impact goal. No single part of the process alone can lead to the impact goal. Each stakeholder has a completely different set of tasks and discipline-specific assumptions on how to contribute to that goal. For example, for the construction company, an important task is to work towards making this type of renovation 'market-conform'. This means that the entire renovation can be provided at a cost that is affordable to the target market, the housing corporations. This in turn means making the building process itself as efficient as possible. It also means doing the renovation in such a way as to conform to national regulations that were set up to make them financially viable, for example air-tightness of the home. For the designer stakeholders, the main task is another one. Net zero-energy means that on balance, the building and its residents produce as much energy as they consume (Sartori, Napolitano and Voss, 2012). This has rarely been achieved to date for this type of housing. The outcome crucially depends on how residents live in their homes, for example, whether they open windows while the heating is on, and whether they understand their home systems. The complexity of these practices, combined with the technical complexity of a building, result in the need, from a design perspective, for an in-depth participation process. The designers' goal of the process is 
therefore: 'satisfied residents in a renovated building that proves to be zero-energy over time'. Satisfied is divided into several sub-criteria such as control, usability, suitability for varying preferences, financial security, comfort and security in looking ahead to the future, based on earlier research with residents (Boess, Silvester and Keizer 2017). While such close attention to resident practices might be easily acceptable to designers, this tends not to be the case in the construction field. New combinations of technologies are being made fast, at the technology implementation rather than development phase. Feedback loops to a design process that could include interface design and adaptation steps do not currently exist in that phase. Combining technologies newly in the implementation phase presents challenges in informing residents well. The interfaces and their combinations can become too complex for residents. For example, in this project the convectors in the home have an interface that only partially fits their actual functionality. When considering how to explain such aspects to the residents, industry stakeholders throughout the process often switched between the contradictory positions of taking away responsibility from residents and allocating them a great deal of responsibility. In the first position, industry stakeholders frequently stated that 'residents should touch and control as little as possible', and 'should not use the (non-functional) interface part'. At the same time, the new combination of installations created some necessary and fairly complex interaction paths the residents had trouble learning and following, such as distinguishing between and responding to five types of temperature: the existing temperatures at head height and the floor level of a room, the selected temperature, the temperature of ventilation air, and the outside temperature. When the industry stakeholders realised that residents would need information on this, they sometimes switched seamlessly from the 'don't touch' position to a position of giving lengthy technical explanations directly to residents, making little use of supporting materials such as visuals or indications of sequence which would have helped convey the required actions. I do not interpret this as a personal shortcoming of these industry stakeholders. Rather, I interpret it as coping responses when becoming aware of the residents' potential in impeding the impact goal. It almost seemed like industry stakeholders were then reassuring themselves by iterating their own knowledge of the systems. These were perhaps their only possible responses in that situation, because they could not change the systems and interfaces at that point. The reason this came about will be addressed next, under 'goal dissipation'.

\subsection{Theme: goal dissipation}

The high-level goal of creating a system that would contribute its part to reducing $\mathrm{CO} 2$ globally was shared by all professional actors in the process. However, it lost importance at times in the networked collaboration. This was due to the influence of business and technical constraints, for example in the contracts between the actors. The contractors had the standard financial parameters for the field, without extra assistance from a funding agency. Not all actors were formally part of the consortium and hence benefitting from the extra financial provision of the funded project. For example, from the installation supplier's perspective, it was a relatively small project in size, which however required a high level of technical alignment - in other words, a project that was already difficult to balance financially, while being small. This particular market, the tenant market, was also not their main target market at this time. In addition, on the building company's side, it was vital for the building company not to invite the installation company into the consortium, in order to retain the freedom of being able to negotiate and select different technical solutions per project. As a result, the installation company delivered only the services as required by law and contract and did not make an extra effort towards aligning the newly combined and not fully congruent systems. This is an example of how the overall impact goal became dissipated along the network chain and affected by regular business constraints.

\subsection{Theme: a contested service interface}

The overall impact goal was furthermore affected, in my view, by the building and installation professionals' idea of what the service comprises that the residents use. While an interface is traditionally understood to be the visible and usable part of a technical system, I started to think of it here more broadly as a heterogenous service interface of the kind that Secomandi and Snelders (2011) propose. According to these authors, an interface comprises of (all of) "the sociotechnical resources immediately associated with exchanges between providers and clients". In this view, the service interface can be said to incorporate, for example, the residents' use of their windows, as well as the ways technical stakeholders communicate with residents, verbally or through manuals. I embraced this 
broader idea of a service interface because all these heterogenous aspects affect the residents' understanding and ability to interact with their home. The aspects thus benefit or pose risks to the overall impact goal. In this case, the physical interface elements to use system functions were incompletely aligned. Only the user manual could still be influenced at this implementation stage. In consequence, it acquired an important role in the service interface, and consequently in my collaboration with the construction and installation stakeholders. Here too there was frequent switching between making it as simple as possible and letting it show effective use of the home given its technical complexity. Initially, the installation and construction stakeholders insisted on compiling the user manual. The manual they created for the residents to use their systems looked like this, in overview (Figure 3): it largely relied on descriptions in text and partially adopted the descriptions of the original systems without adapting them to their changed functionality.
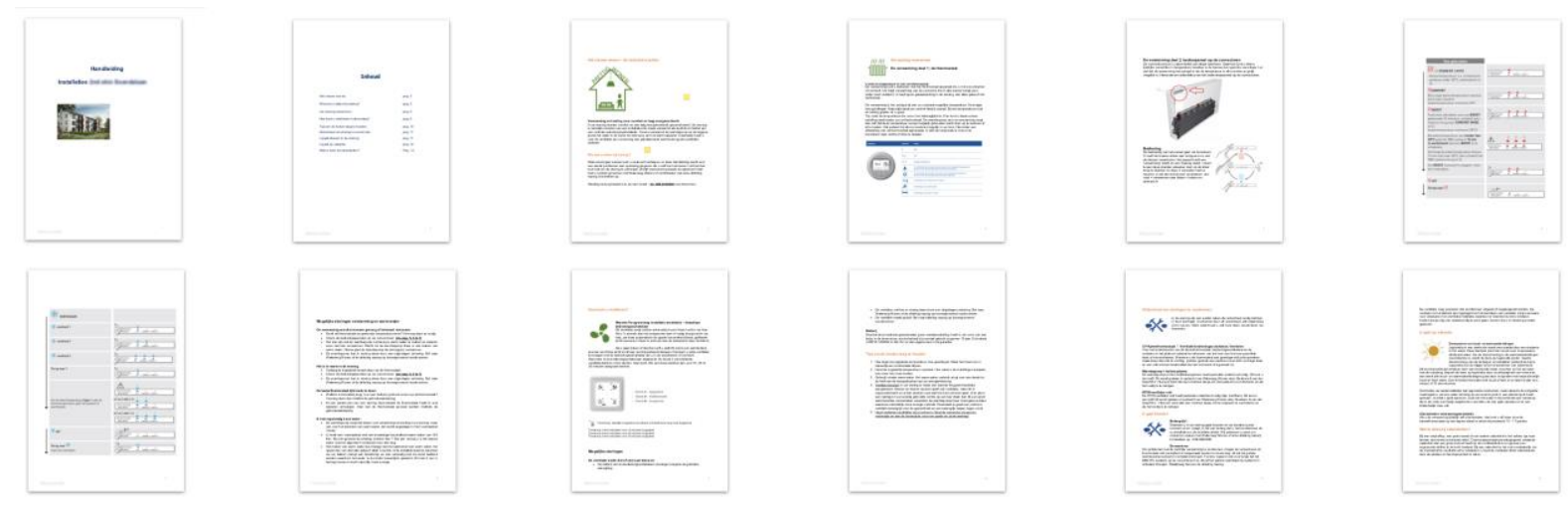

Figure 3. Text-based, isolated information about physical interface elements for residents of their home. The depiction is deliberately small here because it is not about the details but the overall idea.

The technical stakeholders viewed it as their competence and domain to translate technical givens to communication to users and to provide this information to the residents. They were supported by a marketing professional who is an expert in communication, but not in the technical systems. After half a year of using this manual in the renovated, delivered home, it emerged that residents were using their systems in ways that partially benefitted the overall impact goal, but also posed some risks to it as well as to the residents themselves. All of the residents greatly appreciated the improved quality of their homes, for example that the indoor air was much more stable and easier to heat, and that they were now proud of the exterior of their building. However, some of the residents did not engage with their ventilation interfaces, continuing to aerate their homes via windows and doors even though it had been communicated to them verbally that they should not do so. There were complaints from some residents that they felt they could not heat or cool their homes sufficiently, and some turned out not to know how to use their thermostats. In response to these insights, a renewed effort took place, now with more opportunity for input from me and other design researchers. A more image-based manual was developed through intense and consistent care and effort of design stakeholders, as shown in Figure 4. This new manual in turn led to discussions among the stakeholders, because it made the complexity of the home interface in all its aspects apparent. The new manual is now due to be rolled out to the residents, in a stepped approach that includes a very short, one-A4 version and more extensive versions depending on residents' willingness to engage with them. 

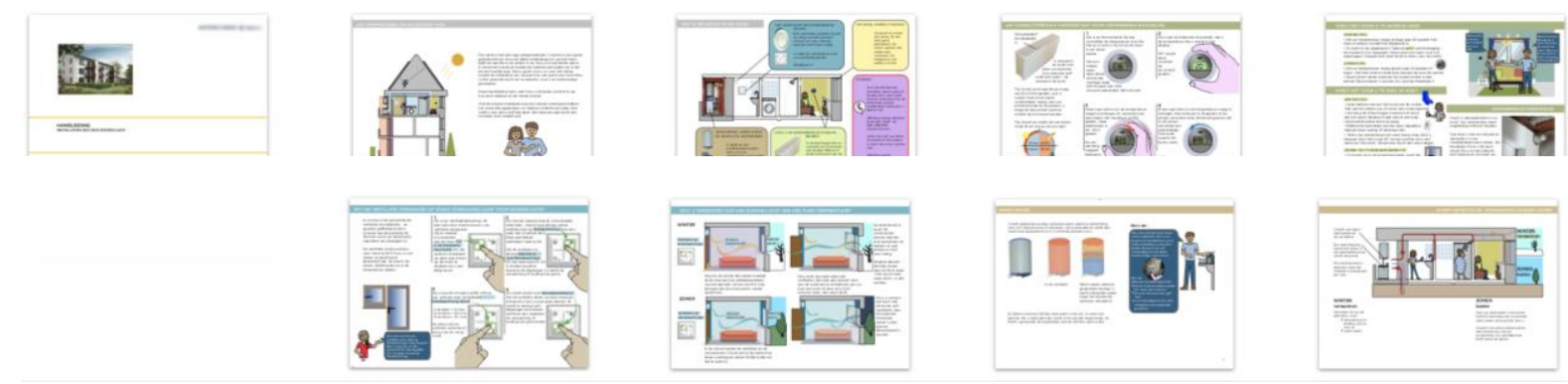

Figure 4. Image-based information for residents that includes the connection between physical interface elements and the residents' own actions in their home. Here too, the depiction is deliberately small because it is not about the details but the overall idea.

\subsection{Theme: contested responsiveness to residents (users)}

Another insight that emerged for me with regard to the concerns of responsible innovation was the responsiveness to the residents. Stilgoe, Owen and MacNaghten (2013) state that inclusion and responsiveness are strongly linked. Only when voices are included and being heard, is responsiveness to their concerns possible. The salience of this is illustrated in the following two tables. They list system decisions, their effect on residents, the resulting residents' reaction (both in my observation), follow-up system decisions and in turn the effects of these on residents as I perceived them. In the case of wanted effects on residents, the picture looks straightforward, and installation and construction stakeholders expressed no need to adapt anything or try to influence residents to change. This is illustrated in Table 1. The effect on the residents and their reaction align each time to produce a desirable outcome.

Table 1. Effects that are intended and understood by the different stakeholders

\begin{tabular}{|l|l|l|l|l|}
\hline $\begin{array}{c}\text { System decision } \\
\text { (distributed across } \\
\text { stakeholders) }\end{array}$ & $\begin{array}{l}\text { Effect on residents } \\
\text { (considered during } \\
\text { planning) }\end{array}$ & Residents' reaction & $\begin{array}{c}\text { Follow-up } \\
\text { system decision }\end{array}$ & $\begin{array}{l}\text { Effect on residents } \\
\text { (considered or not } \\
\text { during planning) }\end{array}$ \\
\hline $\begin{array}{l}\text { Highly insulated } \\
\text { outer walls }\end{array}$ & $\begin{array}{l}\text { Stable indoor } \\
\text { climate, less noise } \\
\text { from outside }\end{array}$ & $\begin{array}{l}\text { Interior is quieter and } \\
\text { also experienced as } \\
\text { quieter }\end{array}$ & No change & No change \\
\hline $\begin{array}{l}\text { Mechanical } \\
\text { ventilation system }\end{array}$ & $\begin{array}{l}\text { Better indoor air, } \\
\text { stable indoor } \\
\text { climate }\end{array}$ & $\begin{array}{l}\text { Enjoy the stable indoor } \\
\text { climate }\end{array}$ & No change & No change \\
\hline $\begin{array}{l}\text { Less visible and } \\
\text { direct heating } \\
\text { system }\end{array}$ & $\begin{array}{l}\text { Better indoor air, } \\
\text { stable indoor } \\
\text { climate }\end{array}$ & $\begin{array}{l}\text { Enjoy the stable } \\
\text { temperature, engage } \\
\text { with heating less } \\
\text { actively }\end{array}$ & No change & No change \\
\hline $\begin{array}{l}\text { Airtight windows, } \\
\text { heavier than before }\end{array}$ & $\begin{array}{l}\text { Less extreme } \\
\text { temperature } \\
\text { changes }\end{array}$ & $\begin{array}{l}\text { Enjoy keeping windows } \\
\text { closed, looking out }\end{array}$ & No change & No change \\
\hline
\end{tabular}

The picture looks different for undesired residents' responses. Installation and construction professionals regard these as direct responses to system decisions. This makes the residents' reactions seem unreasonable to them, as they do not align with the goal of the system. 
Table 2. Effects that are only partially understood by the different stakeholders

\begin{tabular}{|l|l|l|l|l|}
\hline $\begin{array}{l}\text { System decision } \\
\text { (distributed across } \\
\text { stakeholders) }\end{array}$ & $\begin{array}{l}\text { Effect on residents } \\
\text { (considered during } \\
\text { planning) }\end{array}$ & Residents' reaction & $\begin{array}{l}\text { Follow-up } \\
\text { system decision }\end{array}$ & $\begin{array}{l}\text { Effect on residents } \\
\text { (considered or not } \\
\text { during planning) }\end{array}$ \\
\hline $\begin{array}{l}\text { When technologies } \\
\text { are combined in an } \\
\text { unusual way to } \\
\text { provide heating and } \\
\text { ventilation and meet } \\
\text { budget }\end{array}$ & $\begin{array}{l}\text { When physical } \\
\text { interfaces do not fit } \\
\text { with the actual } \\
\text { system function }\end{array}$ & $\begin{array}{l}\text { Residents have } \\
\text { inaccurate ideas how } \\
\text { the system can be } \\
\text { activated }\end{array}$ & $\begin{array}{l}\text { No change in } \\
\text { technical system, } \\
\text { 'residents should } \\
\text { not touch their } \\
\text { systems anyway' }\end{array}$ & $\begin{array}{l}\text { Residents have } \\
\text { inaccurate ideas } \\
\text { how the system can } \\
\text { be activated }\end{array}$ \\
\hline $\begin{array}{l}\text { When each system } \\
\text { part's standard } \\
\text { interface and } \\
\text { explanation is seen } \\
\text { in isolation to stay } \\
\text { true to system } \\
\text { function }\end{array}$ & $\begin{array}{l}\text { When technical } \\
\text { terms are } \\
\text { emphasized in } \\
\text { explanations, and } \\
\text { explainers do not } \\
\text { check whether the } \\
\text { user understood }\end{array}$ & $\begin{array}{l}\text { Residents (continue to) } \\
\text { use the systems } \\
\text { ineffectively }\end{array}$ & $\begin{array}{l}\text { No change in } \\
\text { technical system, } \\
\text { successions of } \\
\text { technical } \\
\text { explanations to } \\
\text { residents, } \\
\text { disappointment } \\
\text { with residents }\end{array}$ & $\begin{array}{l}\text { Residents are } \\
\text { blamed while } \\
\text { residents also } \\
\text { become irritated at } \\
\text { stream of } \\
\text { information coming } \\
\text { their way }\end{array}$ \\
\hline $\begin{array}{l}\text { When window } \\
\text { frames are replaced } \\
\text { to ensure an airtight } \\
\text { building skin for } \\
\text { energy efficiency }\end{array}$ & $\begin{array}{l}\text { When no example } \\
\text { and support is given } \\
\text { how to hang window } \\
\text { blinds }\end{array}$ & $\begin{array}{l}\text { Residents drill holes } \\
\text { into plastic window } \\
\text { frames }\end{array}$ & $\begin{array}{l}\text { No change in } \\
\text { technical system }\end{array}$ & $\begin{array}{l}\text { Residents face } \\
\text { possible sanctions } \\
\text { because they are } \\
\text { damaging the }\end{array}$ \\
\hline building
\end{tabular}

However, my interactions with the residents over time indicated that mediating effects often influenced the residents' reaction. Viewed that way, the residents' reaction made more sense. The installation and construction stakeholders were often reluctant to engage with this more complex picture, preferring to resort either to the 'don't touch' or to the explaining response described above, rather than acknowledging and acting upon the mediation. A more responsive position is still a challenge to be developed further in this field. Why did the construction and installation professionals respond negatively to the undesired resident actions as shown in Table 2? I interpreted the negative responses as a sign of stress, because the professionals already faced several critical issues to make the project succeed. One construction stakeholder expressed it this way: "Nobody of this consortium group was aware of how important one specific thing was in this whole process. That was to pass the test of air-tightness of the home. During the entire process, I had to devote a large portion of my resources to ensuring this would succeed. This had to have priority (over interface decisions) because the project's whole business model would fail if this did not succeed." Stress may make it more difficult to develop a responsiveness to the mediated and in themselves complex interactions that residents have in and with their homes. At one point during the process, one of the construction partners asked one of the design partners: "You are not technical - are you?" Industrial design professionals can be confusing partners for technical professionals in the building field, because the design professionals are not fully experts of the technical domain, yet they assert and demonstrate opinions and intentions related to the technical experts' domain. As shown in the previous theme section on the service interface, designers can mitigate this confusion by consistently coming back to the residents' perspective and demonstrating care in designing artefacts to support it.

\section{DISCUSSION}

What are the contributions of a design approach in a building process with its stakeholders?

How do the activities and deliverables promote or impede responsible innovation? I set out to argue that designers can engage through design intervention and applying care in the collaboration, in order to support the improvement of responsible innovation. The paper has shown that designers can have an important contribution in aiming for responsible innovation goals. I have identified four thematic sites at which responsible innovation faces risks and possibilities that affect an overall impact goal. The four sites identified in this case study are goal translation, goal dissipation, the contested service interface and the contested responsiveness to residents (as one type of 'user' group). Because this is a case study, it is out of the scope of this paper to speculate whether these four sites are generally the most critical or prevalent, or whether there are many more. The examples have shown that a case of 
responsible innovation can be at risk from the complexity of its object, that there are limitations to the scope that design can directly address, but that design can employ strategies to contribute benefits to responsible innovation. These strategies should be explored further. The kind of examples shown, such as user manuals, are not new in design. The specific details of the user manuals are not the point being made here. The point is about their potential as artefacts in opening up discussions about complexity, inclusion and responsiveness within a responsible innovation project effort. I cannot make any assertions yet about anticipation, but I hope that the learnings can be transferred into an anticipation effort for follow-up projects. The examples shown highlight key issues in moving forward in designing responsible future product and service systems. Designers are likely to understand that systems are not only technical systems, and how to make interfaces work for users. In this field, designers also need an understanding of other stakeholders who can choose to work with designers or not and for whom a designers' role can be unexpected and unclear. Designers can develop an understanding of how these other stakeholders understand the systems they are designing, and that this understanding may not change overnight. For this project, the collaboration on the user manual is only a consolation prize from the perspective of design, since it would have been preferable to improve the interfaces themselves, and the whole system in which they are connected. Another remaining challenge lies in the human dimension of service. Often, residents are reticent to engage with their interfaces and with user manuals in the first place. The manual as an object, as a tangible deliverable was a useful object for discussion among stakeholders. Yet it falls short of a more comprehensive understanding of service interface (Secomandi and Snelders 2011). The challenge remains to engage the installation and construction stakeholders in the design of their own interactions with residents, in terms of what they say and how they say it, and which parts of this can be automated or not.

The interaction with designers too is challenging for professionals in the building field. During an early conflict in which the designers asked for more input into the systems, the building company stakeholders tried to solve it by proposing to separate work packages. With that, they sought to keep the peace and not engage with a set of demands that seemed incomprehensible. However, a continued mutual engagement eventually leads to an increase in acceptance, if not full understanding of another position. Such continued, open-minded, listening engagement is in alignment with Light and Akama's (2012) careful discussion of human attitudes in designing with communities. Arguably, these attitudes and understandings contribute to promoting that these new kinds of homes will be comfortable and healthy, as well as zero-energy and thus helping to reduce global $\mathrm{CO} 2$ emissions.

\section{ACKNOWLEDGMENTS}

Thanks go to the 2ndSkin team and the case study households for participating in this study. The 2ndSkin project is co-financed by the Building Technology Accelerator/ ClimateKIC.

\section{REFERENCES}

Bergvall-Kåreborn, B. and Ståhlbrost, A. (October 2008), "Participatory design: one step back or two steps forward?", In Proceedings of the 10th Participatory Design Conference, pp. 102-111. Indiana University.

Blomberg, J. and Karasti, H. (2012), "Positioning ethnography within participatory design", Routledge international handbook of participatory design, pp. 86-116.

Boess, S. and Kanis, H. (2008), "Meaning in product use: A design perspective", In Product experience pp. 305-332. Elsevier.

Boess, S., Silvester, S. and Keizer, H. (2017), "Unpublished research report", Delft University of Technology.

Boess, S., Silvester, S., de Wal, E. and de Wal, O. (August 2018), "Acting from a participatory attitude in a networked collaboration”, In Proceedings of the 15th Participatory Design Conference: Short Papers, Situated Actions, Workshops and Tutorial Vol. 2 p. 16. ACM.

Chiu, L.F., Lowe, R., Raslan, R., Altamirano-Medina, H. and Wingfield, J. (2014), "A socio-technical approach to post-occupancy evaluation: interactive adaptability in domestic retrofit. Building Research \& Information", Vol. 42 No. 5, pp. 574-590.

Coutts, E.R., Edward, J., Knight, R., Duffy, A. and Grierson, H. (2017), “Is product design evil?”, In DS 87-1 Proceedings of the 21st International Conference on Engineering Design (ICED 17), Vancouver, Canada, 21-25.08. 2017 pp. 209-218.

De Lille, C. and Buur, J. (2010), "Participatory innovation in SMEs", In Proceedings of the 11th Biennial Participatory Design Conference, pp. 277-278. ACM.

Elzen, v.d., S. (2018), "Unpublished Master thesis”, Delft University of Technology. 
EU. undated. "Statistics on small and medium-sized enterprises", Accessible at http://ec.europa.eu/eurostat/statistics-explained/index.php/Statistics_on_small_and_mediumsized_enterprises.

Guerra-Santin, O., Bosch, H., Budde, P., Konstantinou, T., Boess, S., Klein, T. and Silvester, S.J.E.E. (2018), "Considering user profiles and occupants' behaviour on a zero energy renovation strategy for multi-family housing in the Netherlands. Energy Efficiency", Vol. 11 No. 7, pp. 1847-1870.

Light, A. and Akama, Y. (2012 August), "The human touch: participatory practice and the role of facilitation in designing with communities", In Proceedings of the 12th Participatory Design Conference, pp. 61-70. ACM.

Pasman, G., Boess, S. and Desmet, P. (2011), "Interaction vision: expressing and identifying the qualities of user-product interactions", In DS 69: Proceedings of E\&PDE 2011, the 13th International Conference on Engineering and Product Design Education, London, UK, 08.09.09. 2011.

Sartori, I., Napolitano, A. and Voss, K. (2012), "Net zero energy buildings: A consistent definition framework. Energy and buildings", Vol. 48, pp. 220-232.

Secomandi, F. and Snelders, D. (2011), "The object of service design. Design Issues”, Vol. 27 No. 3, pp. 20 -34.

Stilgoe, J., Owen, R. and Macnaghten, P. (2013), "Developing a framework for responsible innovation”, Research Policy, Vol. 42 No. 9, pp. 1568-1580. 